\title{
UNIB PEDULI TENAGA MEDIS PEJUANG COVID-19
}

\author{
Nurmukaromatis Saleha ${ }^{1}$, Dri Asmawanti ${ }^{2,}$ Rina Delfina $^{3}$ \\ ${ }^{1,3)}$ Keperawatan, Fakultas MIPA, Universitas Bengkulu \\ 2) Akutansi, Fakultas Ekonomi, Universitas Bengkulu \\ e-mail: nsaleha@unib.ac.id
}

\begin{abstract}
Abstrak
Risiko kerja tenaga medis dalam memberikan pelayanan kesehatan telah menjadikan mereka sebagai cluster terkonfirmasi positif Covid-19. Sebagai garda terdepan penanganan wabah ini maka diperlukan perhatian khusus terhadap mereka. Pengabdian masyarakat ini dilakukan di RSUD dr. M.Yunus Bengkulu dengan tujuan untuk memberikan dukungan sosial kepada tenaga medis. Bentuk kegiatan berupa pemberian donasi bubuk jahe, kunyit temulawak sebagai minuman suplemen yang dapat meningkatkan imunitas. Ramuan tersebut mengandung Curcumin yang dapat mencegah terjadinya badai sitokin respon biologis terhadap virus Corona yang dapat membahayakan jiwa. Tahapan kegiatan berupa pembuatan suplemen Bersama mitra masyarakat dan tahapan distribusi suplemen ke RSUD dr. M. Yunus. Sebanyak 250 bungkus bubuk diberikan dalam dua tahap. Hasil evaluasi tenaga medis merasakan khasiat minuman tersebut dalam menjaga stamina. Simpulan yang dapat diambil dari kegiatan ini adalah dukungan sosial masyarakat merupakan salah satu faktor yang dapat meningkatkan ketahanan fisik dan mental tenaga medis. Menimbang kemungkinan serta efek pandemi yang panjang maka kegiatan-kegiatan serupa perlu dipertahankan.
\end{abstract}

Kata kunci: Covid-19, Imunitas, Suplemen Curcumin, Tenaga Medis

\begin{abstract}
The occupational risk of medical personnel in providing health services has made them a cluster confirmed positive for Covid-19. This community service was carried out at dr. M. Yunus Bengkulu with the aim of providing social support to medical personnel. The activity is in the form of giving donations of ginger powder, turmeric, ginger as a supplement drink that can increase immunity. This herb contains curcumin which can prevent cytokine storms from a biological response to the Corona virus which can endanger lives. Stages of activity in the form of making supplements with community partners and distribution stages of supplements to dr. M. Yunus. A total of 250 packs of powder were given in two stages. The results of the evaluation of medical personnel felt the efficacy of these drinks in maintaining stamina. The conclusion that can be drawn from this activity is that community social support is one of the factors that can increase the physical and mental resilience of medical personnel.
\end{abstract}

Keywords: Covid-19, Immunity, Curcumin Supplements, Medical Personnel

\section{PENDAHULUAN}

Akhir Maret 2020 Gubernur Bengkulu mengumumkan kasus pertama Covid-19 maka sejak itu Bengkulu dinyatakan sebagai Red Zone (CNBC, 2020). Penambahan jumlah kasus dari hari ke hari cukup signifikan. Kondisi ini tentu berdampak pada tenaga medis yang menjadi garda terdepan dalam penanganan Covid-19. Sifat profesi mereka sebagai pemberi layanan Kesehatan menempatkan mereka pada risiko tinggi keterpaparan virus corona penyebab Covid-19. Covid-19 menimbulkan dampak fisik maupun psikologis bagi tenaga medis. Perubahan pola kerja yang menimbulkan kelelahan, pemakaian Alat Pelindung Diri (APD) dalam waktu lama, kecemasan akan tertular dan menularkan penyakit pada keluarga, menjalani proses pemeriksaan kesehatan yang memberikan rasa ketidanyamanan fisik, pengalaman karantina dan yang tak kalah mencemaskan adalah menghadapi stigma masyarakat.

Kondisi psikologis membawa dampak terhadap kondisi kesehatan secara umum. Kelelahan serta kecemasan dapat berkontribusi negatif terhadap imunitas tubuh individu. Semua itu tentunya dapat memengaruhi performa kerja tenaga medis (Barzilay et al., 2020; Kackin et al., 2020; Kılınç \& Sis Çelik, 2020; Lohmann et al., 2019). Tak dapat dipungkiri peran tenaga medis sangat 
dibutuhkan pada masa pandemi ini. Mengingat hal tersebut maka dukungan sosial dari berbagai sumber menjadi penting untuk mempertahankan Kesehatan tenaga medis.

Kegiatan pengabdian masyarakat ini merupakan bentuk kepedulian Universitas Bengkulu terhadap pandemi Covid-19 yang telah berdampak luas termasuk di Kota Bengkulu ini. Tim menunjukkan kepedulian tersebut dengan membuat suplemen minuman sehat yang dapat membantu meningkatkan stamina dan imunitas tubuh. Suplemen yang dimaksud berupa ramuan yang mengandung Curcumin yang terkandung dalam Jahe, Kunyit dan Temulawak.

Curcumin merupakan senyawa yang mengandung zat anti inflamasi/radang. Potensi farmakologis tersebut dapat menghambat aktivitas virus SARS Cov-2 sebagai penyebab Covid-19. Ketika virus menginfeksi tubuh terutama paru terjadilah respon biologis tubuh dengan membentuk sitokin. Sitokin yang terbentuk secara berlebihan justru memberikan dampak negative pada tubuh akibat peradangan yang ditimbulkannya. Curcumin menjadi penangkal badai sitokin. Beberapa penelitian menunjukkan khasiat curcumin sebagai anti peradangan yang direkomendasikan sebagai terapi penunjang Covid-19 (Oso et al., 2020; Prabha et al., 2020; Rocha \& de Assis, 2020; Soni et al., 2020; Zahedipour et al., 2020). Berdasarkan hasil-hasil penelitian tersebut maka donasi berupa bubuk JKT tepat diberikan guna membantu tenaga medis dalam menjaga stamina tenaga medis.

Tujuan dari kegiatan adalah untuk memberikan dukungan sosial kepada tenaga medis yang tengah berjuang sebagai garda terdepan. Dukungan tersebut dalam bentuk pemberian donasi minuman suplemen untuk meningkatkan imunitas berupa bubuk Jahe, Kunyit dan Temulawak.

\section{METODE}

Kegiatan ini dilaksanakan pada bulan Mei 2020. Kegiatan diawali dengan mencari mitra masyarakat yang memiliki potensi dalam mengolah Jahe, kunyit dan temulawak menjadi bubuk yang dapat dikonsumsi sebagai suplemen. Kami menemukan sebuah industri rumah tangga yang sedang mati suri. Ibu Susi seorang warga Desa Kandang Kota Bengkulu sebelumnya memang telah membuat ramuan bubuk jahe. Ia adalah ketua dari Usaha Kecil Menengah (UKM) yang memproduksi Bubuk Jahe yaitu UKM Ummu Habib. Namun karena kurang peminatnya serta faktor teknis dimana kondisi ibu Susi sebagai Ibu rumah tangga dengan anak balita maka kegiatan produksi terhenti. Ketika wabah Covid-19 melanda keluarga ini ikut terkena dampak karena suami ibu Susi yang dirumahkan. Covid-19 sendiri memang tak hanya berdampak pada bidang kesehatan saja, melainkan hampir semua bidang seperti ekonomi, pendidikan, pariwisata bahkan sosial politik. Melihat kondisi ini maka kami menjadikan ibu Susi sebagai mitra masyarakat yang dapat membantu kegiatan pengabdian masyarakat untuk produksi bubuk Jahe Kunyit Temulawak.

Rimpang yang banyak ditemukan di di kawasan Asia Tenggara khususnya Indonesia adalah Jahe (Zingiber officinale Rosc) keluarga Zingiberaceae merupakan suatu jenis rimpang yang banyak ditemukan. Jahe sering digunakan sebagai bumbu masakan. Jahe segar dikelompokkan menjadi dua kategori besar, yaitu volatil dan non-volatil. Volatil meliputi hidrokarbon seskuiterpen dan monoterpenoid yang memberikan aroma dan rasa jahe yang berbeda. Sebaliknya, senyawa pedas yang tidak mudah menguap meliputi gingerol, shogaol, paradol, dan zingerone. Fitokimia yang banyak terkandung dalam jahe berkhasiat dalam meningkatkan sistim kekebalan tubuh. Bersama dengan temulawak jahe sering dibuat menjadi herbal yang berguna sebagai pengobatan tradisional (Mahassni \& Bukhari, 2019).

Jahe memiliki sifat anti inflamasi (anti peradangan) dan potensi antimikroba yang dapat mengobati berbagai penyakit menular. Mahassni \& Bukhari di tahun 2019 menulis bahwa jahe memiliki manfaat untuk meningkatkan daya tahan tubuh. Ekstrak jahe dapat meningkatkan neutrofil dan sel darah merah. Orang dengan anemia atau kekurangan darah baik mengkonsumsi jahe guna meningkatkan kadar sel darah merah.

Kunyit dan temulawak kaya dengan curcumin. Curcumin mampu berikatan dengan reseptor protein SARS-CoV 2 yaitu melalui ikatan dengan domain protease (6Lu7) dan spike glikoprotein. Ikatan ini berpotensi untuk menghambat aktivitas Covid-19. Selain itu curcumin diketahui menghambat pelepasan senyawa tubuh penyebab peradangan atau sitokin proinflamasi seperti interleukin-1, interleukin-6 dan tumor necrosis factor- $\alpha$. Yuli Widiyastuti, dkk, Humas Litbang kemkes 2020. Prof Chairul Nidom Guru Besar Biokimia dan Biologi dari Universitas Airlangga menyatakan bahwasanya curcumin dapat menangkal terjadinya badai sitokin. Sitokin merupakan senyawa yang akan dikeluarkan karena proses biologis tubuh akibat dari serangan virus. Kondisi 
badai sitokin ini terjadi pada infeksi-infeksi turunan virus corona baik pada SARS dan MERS maupun Covid-19. Badai sitokin yang terjadi pada paru menyebabkan peradangan dan menimbulkan gejala pernapasan yang berat hingga kematian (Felsenstein et al., 2020).

Selanjutnya kami melakukan pendampingan kepada ibu Susi yang dibantu dengan warga sekitar dalam pembuatan JKT. Ibu Susi biasanya hanya membuat bubuk Jahe saja, sementara curcumin banyak dikandung oleh Kunyit dan temulawak. Kami berdiskusi tentang penambahan komposisi yang kami sesuaikan dengan tujuan kegiatan yaitu pemberian curcumin untuk meningkatkan imunitas. Adapun komposisi dari ramuan ini adalah Jahe, Kunyit, Temulawak, Serai, Kapulaga, Cengkeh dan gula pasir. Pengolahan dilakukan secara hygienis. Bahan-bahan dikupas kemudian digiling. Untuk penggilingan menggunakan jasa pihak ke tiga.

\section{HASIL DAN PEMBAHASAN}

Hasil kegiatan ini berupa produksi bubuk Jahe Kunyit Temulawak sebanyak 250 bungkus dengan berat 250 gram setiap bungkusnya. Adapun tahapan kegiatan adalah sebagai berikut:

\section{Tahap Persiapan}

Pada tahap persiapan dilakukan koordinasi antara tim dengan LPPM dan mitra sasaran pengabdian. Berikutnya dilakukan penyusunan jadwal kegiatan dan pembagian tugas antar anggota tim. Mitra sasaran pada kegiatan ini adalah Usaha Kecil Menengah (UKM) yang memproduksi Bubuk Jahe yaitu UKM Ummu Habib. UKM ini beralamat di Jl. Pulung Mas Kota Bengkulu. Setelah bubuk JKT terbentuk dilakukan pengkemasan dalam kantong 250 gram. Tahapan pembuatan ini dibagi menjadi dua tahap, hal tersebut menimbang kemampuan produksi dan waktu yang kebetulan saat itu menjelang hari Raya Idul fitri. Tahap pertama menghasilkan bubuk JKT sebanyak 120 bungkus. Di tahap ke dua proses produksi dilakukan setelah hari raya Idul Fitri menghasilkan 130 bungkus JKT. Kegiatan penyerahan donasi dilakukan dalam dua tahap karena menimbang kemampuan produksi dan kondisi saat itu yang menjelang Hari Raya Idul Fitri.

\section{Tahap Pelaksanaan Kegiatan}

Tahap satu kegiatan ini dilaksanakan pada hari Senin tanggal 18 Mei 2020 bertempat di ruang Komite Keperawatan. Donasi diterima oleh ibu Marti Yuseva, S.Kep selaku Sub Komite Etika dan Disiplin Profesi Keperawatan. Tahap pertama dilakukan penyerahan donasi sebanyak 120 bungkus bubuk Jahe Kunyit Temulawak (JKT) beserta telur ayam sebanyak 10 karpet untuk tenaga medis di RSUD dr.M.Yunus Bengkulu. Tahap ke dua dilaksanakan setelah hari raya Idul Fitri tepatnya di tanggal 03 Juni 2020. Donasi yang diserahkan berupa 130 bungkus JKT dan telur ayam sebanyak 10 karpet.

Tabel 1

Output pelaksanaan kegiatan yang telah capai

\begin{tabular}{|c|c|}
\hline Aspek & Target Luaran \\
\hline Produksi & $\begin{array}{l}\text { Ramuan bubuk jahe, kunyit dan temu lawak sebanyak } 250 \\
\text { bungkus. }\end{array}$ \\
\hline Kemanusiaan & $\begin{array}{l}\text { Paket produk yang akan disumbangkan ke RSUD DR M. } \\
\text { Yunus Bengkulu sebagai suplemen nutrisi bagi tenaga } \\
\text { medis }\end{array}$ \\
\hline Luaran PPM & $\begin{array}{l}\text { Publikasi di media youtube dan media LPPM Online, } \\
\text { peningkatan kesehatan tenaga medis dalam menanggulangi } \\
\text { Covid-19 }\end{array}$ \\
\hline
\end{tabular}




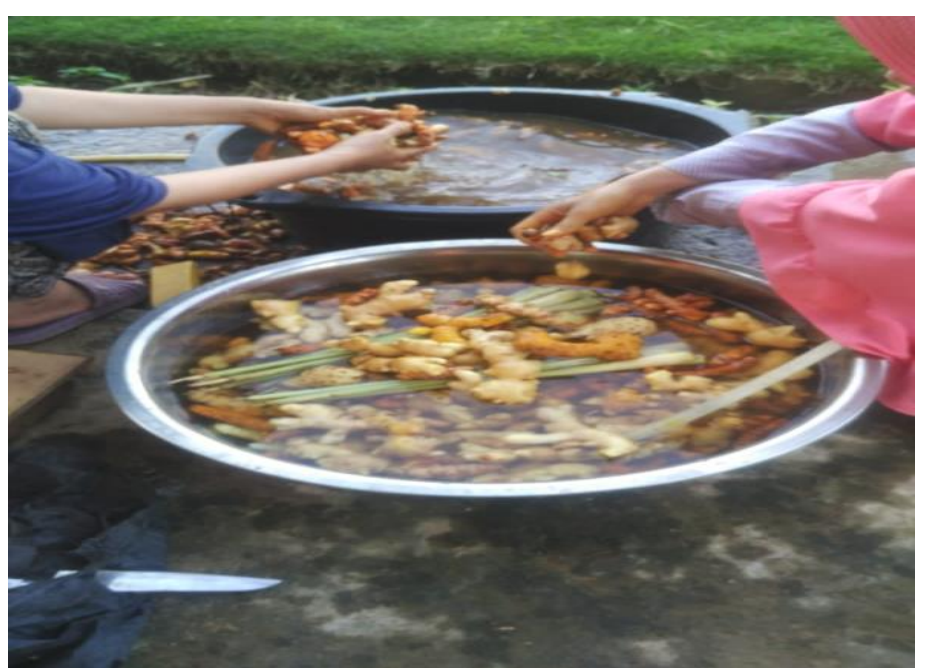

Gambar 1 Pencucian bahan-bahan untuk membuat ramuan Bubuk Jahe, Kunyit Temulawak

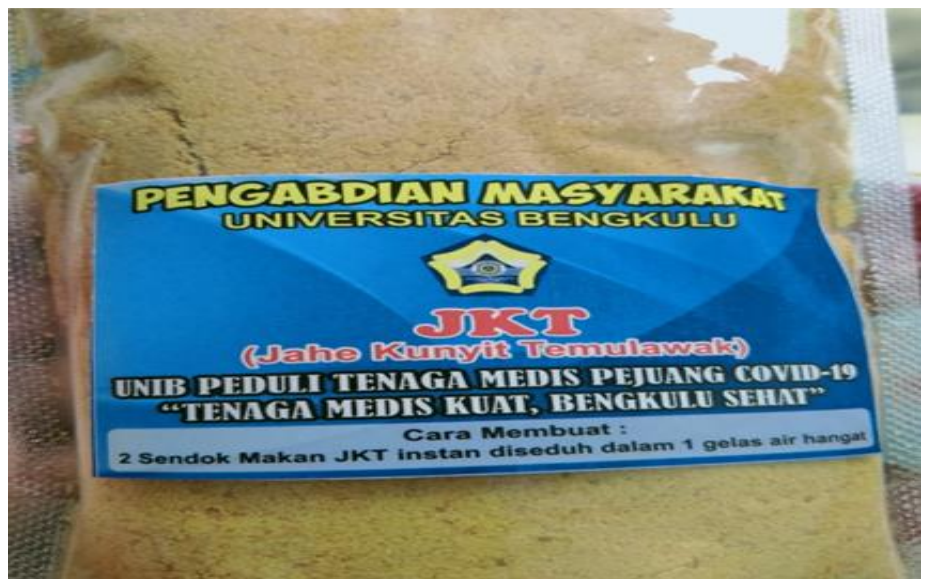

Gambar 2 Pengemasan ramuan Bubuk JKT untuk Tenaga Medis RSUD dr.M.Yunus Bengkulu
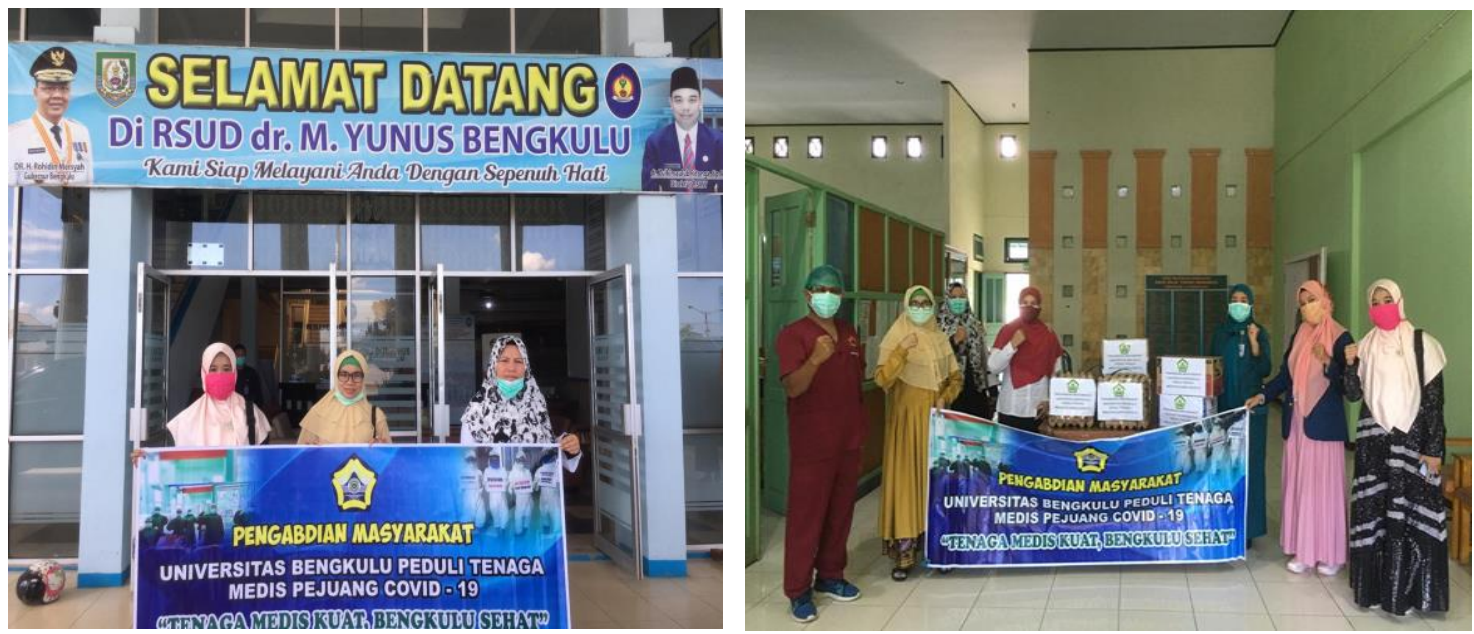

Gambar 3 Penyerahan donasi tanggal 03 juni 2020 di RSUD dr.M.Yunus Bengkulu

\section{SIMPULAN}

Pandemi Covid-19 menjadi suatu tantangan besar bagi tenaga medis sebagai garda terdepan. Dukungan sosial dari berbagai sumber sangatlah penting untuk meningkatkan ketahanan fisik dan mental tenaga medis. Pemberian suplemen nutrisi berupa herbal Jahe Kunyit Temulawak dapat memberikan khasiat sebagai terapi pendamping dalam mengatasi SARS-CoV 2 dan menjaga stamina tubuh.

Pandemi Covid-19 merupakan bencana non alam yang dampaknya bisa menjadi bencana sosial. Semua bentuk bencana menyebabkan adaptasi holistik bio, psiko, sosio bagi individu 
terdampak bencana. Hal tersebut membutuhkan penanganan holistik dan terpadu dari berbagai elemen. Baik elemen pemerintah maupun elemen masyarakat. Kegiatan-kegiatan yang melibatkan masyarakat perlu dilakukan secara kontinuitas. Kegiatan tersebut bisa berupa penggalangan bantuan fisik maupun materiil. InsyaAllah dengan kebersamaan kita akan mampu melewatkan musibah ini.

\section{UCAPAN TERIMA KASIH}

Kegiatan pengabdian masyarakat ini terlaksana dengan dana PNBP LPPM Universitas Bengkulu dengan no kontrak 1515/UN30.15/AM/2020. Kami tim pengabdian mengucapkan terimakasih kepada LPPM yang telah memberikan kesempatan kepada kami untuk menjalankan kegiatan ini. Tak lupa juga kami haturkan ucapkan terimakasih kepada semua pihak yang telah membantu pelaksanaan kegiatan ini seperti pihak UKM "Ummu Habib", pihak manajemen RSUD dr. M.Yunus Bengkulu.

\section{DAFTAR PUSTAKA}

Barzilay, R., Moore, T. M., Greenberg, D. M., DiDomenico, G. E., Brown, L. A., White, L. K., Gur, R. C., \& Gur, R. E. (2020). Resilience, COVID-19-related stress, anxiety and depression during the pandemic in a large population enriched for healthcare providers. Translational Psychiatry, 10(1). https://doi.org/10.1038/s41398-020-00982-4

Felsenstein, S., Herbert, J. A., Mcnamara, P. S., \& Hedrich, C. M. (2020). COVID-19: Immunology and treatment options. January.

Kackin, O., Ciydem, E., Aci, O. S., \& Kutlu, F. Y. (2020). Experiences and psychosocial problems of nurses caring for patients diagnosed with COVID-19 in Turkey: A qualitative study. International Journal of Social Psychiatry. https://doi.org/10.1177/0020764020942788

Kılınç, T., \& Sis Çelik, A. (2020). Relationship between the social support and psychological resilience levels perceived by nurses during the COVID-19 pandemic: A study from Turkey. Perspectives in Psychiatric Care, June, 1-9. https://doi.org/10.1111/ppc.12648

Lohmann, J., Shulenbayev, O., Wilhelm, D., Muula, A. S., \& De Allegri, M. (2019). Psychological wellbeing in a resource-limited work environment: Examining levels and determinants among health workers in rural Malawi. Human Resources for Health, 17(1), 1-11. https://doi.org/10.1186/s12960-019-0416-y

Mahassni, S. H., \& Bukhari, O. A. (2019). Beneficial effects of an aqueous ginger extract on the immune system cells and antibodies, hematology, and thyroid hormones in male smokers and non-smokers. Journal of Nutrition and Intermediary Metabolism, 15(July 2018), 10-17. https://doi.org/10.1016/j.jnim.2018.10.001

Oso, B. J., Adeoye, A. O., \& Olaoye, I. F. (2020). Pharmacoinformatics and hypothetical studies on allicin, curcumin, and gingerol as potential candidates against COVID-19-associated proteases. Journal of Biomolecular Structure and Dynamics, $O(0)$, 1-12. https://doi.org/10.1080/07391102.2020.1813630

Prabha, T., Dhanabal, P., Selvamani, P., Latha, S., Sivakumar, T., \& Jubie, S. (2020). Hydroxychloroquine and curcumin conjugates as multifunctional co drugs for the potential treatment of COVID-19: An in-silico based study. International Journal of Research in Pharmaceutical Sciences, 11(Special Issue 1), 348-359. https://doi.org/10.26452/ijrps.v11iSPL1.2725

Rocha, F. A. C., \& de Assis, M. R. (2020). Curcumin as a potential treatment for COVID-19. Phytotherapy Research, 34(9), 2085-2087. https://doi.org/10.1002/ptr.6745

Soni, V. K., Mehta, A., Ratre, Y. K., Tiwari, A. K., Amit, A., Singh, R. P., Sonkar, S. C., Chaturvedi, N., Shukla, D., \& Vishvakarma, N. K. (2020). Curcumin, a traditional spice component, can hold the promise against COVID-19? European Journal of Pharmacology, 886(July), 173551. https://doi.org/10.1016/j.ejphar.2020.173551

Zahedipour, F., Hosseini, S. A., Sathyapalan, T., Majeed, M., Jamialahmadi, T., Al-Rasadi, K., Banach, M., \& Sahebkar, A. (2020). Potential effects of curcumin in the treatment of COVID-19 infection. Phytotherapy Research, May, 2911-2920. https://doi.org/10.1002/ptr.6738 